\title{
Computer Simulation of Historical Processes and Phenomena: the Russian Experience
}

\author{
Leonid I. Borodkin* \\ Lomonosov Moscow State University \\ 1 Leninskie Gory, Moscow, 119991, Russia
}

Received 07.04.2016, received in revised form 29.05.2016, accepted 18.06.2016

\begin{abstract}
Simulation of historical processes has specific features characterized by the fact that it does not aim at prediction of future development. Over 40 years of its development, it has been a long way for this area of historical computer science in Russia. In this paper we propose a typology of approaches to such simulation in economic and social history, provide a brief overview of the experience gained by the Russian historians in this developing area.
\end{abstract}

Keywords: computer simulation, mathematical models, counterfactual simulation, synergetics, cliodynamics.

DOI: 10.17516/1997-1370-2016-9-7-1562-1571.

Research area: history.

The problem of historical processes and phenomena simulation is of a strongly marked specificity, characterized by the fact that simulation in this case (as compared to most social sciences) is not aimed at prediction of future development. In our country the first works on computer simulation of historical processes were published in the second half of the 1970s and caused heated debates (Guseinova, Kuzishchin, Pavlovskii, Ustinov 1976; Koval'chenko 1978).

\section{Typology of computer models of historical processes}

Three types of computer models can be distinguished, the types being approved by the historians. Models of the first type describe the reality under the analysis invariantly, the reality that actually existed. It is a measuring simulation based on the detection and analysis of statistical interactions in the system of indicators, characterizing the process or the object under the analysis. Here the matter is testing of the hypotheses with the mathematical statistics methods (these are mostly regression models).

Computer models, the application of which is not limited to source data processing, were also taken up. These models may be aimed at reconstruction of missing data on the dynamics of the analysed process at a certain time interval; analysis of the historical development alternatives; theoretical study of possible behavior of the analysed phenomenon (or class of phenomena) on the developed mathematical model. This model type can fit into simulation and analytical ones

(c) Siberian Federal University. All rights reserved

* Corresponding author E-mail address: lborodkin@mail.ru 
(Borodkin 1995). In the study of the past, when a researcher deals with an already accomplished reality, simulation modeling has its own specifics compared to the simulation of the subsequent development of current reality. The experience gained makes it possible to distinguish two types of simulation models: simulation-counterfactual and simulation-alternative models of historical processes.

Computer models can be an effective tool for studying alternative historical situations. Simulation of one or another possible outcome will result in a deeper understanding of the real course of historical development and the objective meaning of the struggle of social forces for one or another variant of this development (Koval'chenko 2003). In 1980s-1990s computer models helped to get significant results in the study of social mobility in NEP period (Borodkin, Svishchev 1995), population and demographic processes in the Paleolithic era (Nosevich 1994), etc. Publication of "Mathematical Modelling of the Historical Processes" collected works in 1996 (Matematicheskoe modelirovanie... 1996) summed up the results of the first twenty years of the development of the methodology of computer simulation of historical processes in the USSR/Russia. The problem of correlation of a model of the analysed historical process, the theories that explain them and the empirical data available as well as the problem of verification of models of different types were set up at this stage. It was shown that mathematical models of a deductive type can be classified on the basis of various principles. In our previous works (Borodkin 1990) we focused on two significant aspects of such classification.

1. It is worth while starting with the ratios expressing the dependence between the states and parameters of the simulated system. The following possibilities arise here: a) the states of the system at a given time are uniquely identified through the system parameters, input data and initial conditions. It is a case of the so-called deterministic models;

b) the above ratios can help to identify (uniquely as well) only the probability distribution for the system states, if the probability distributions for initial conditions, system parameters and input data are specified. This model is termed as probabilistic (stochastic).

2. In the aspect of the method of the mathematical model development and its further application to study the system under the analysis the models can be divided into analytical and simulation ones.

(a) Analytical models imply that processes of the system elements functioning are written in the form of certain functional relations (equations). The analytical model can be analyzed either analytically in order to obtain explicit dependencies (decisions) for the dependent variables in their general form or numerically in order to obtain numerical results using the computer specialized software packages if it is impossible to solve these equations in a general form.

b) Simulation models approximately reproduce the analysed process in its functioning over time. They simulate elementary phenomena of the process at preserving their logical structure and sequence of flow in time. Modelling algorithm makes it possible to obtain data on the states of the process at each subsequent step basing on the data containing information about the initial state of the process (input data) and its parameters. As compared to analytical models, the main advantage of simulation models is a possibility to simulate quite complex processes (with a large number of variables, nonlinear dependencies, feedback loops) that are not subject to analytical research.

It shoud be noted that in the 1990s there appeared the historians' work in which these 
types of models are "intertwoven" and go beyond the scope of this classification. Thus, A.L. Ponomarev's works (Ponomarev 1996) demonstrate the possibilities of the "combined" simulation for solving the tasks of reconstructing the data which are missing in the source under the analysis. The author refers to two different subjects of the Byzantine history of the XIXIV centuries, analysed with one method, in fact. The method applies the known Zipf's law (or, rather, its modification) to extrapolate the number of objects, the frequency of which in the population under the research is equal to zero. Another area of historical knowledge, where "mixed type" models are successfully applied, is historical demography. V.L. Nosevich (Nosevich 1996) considers the possibilities of modelling the dynamics of historical (or, rather, prehistorical) communities evolving towards self-organization. This approach naturally leads the author to the discussion of the concepts of synergetics. His computer model of the early Paleolithic society dynamics simulates the process of a demographic reproduction of the "economic groups" while taking into account a cultural factor as well as random fluctuations in the state of natural environment causing the intensification of migration processes. The simulation model made it possible to "trace" the process of many genealogical lines' survival in the course of tens of thousands of years, having identified geographical areas in which certain populations dominated.

Domestic quantitative history has some experience in application of models that do not belong to the reflective measurement models type (Khvostova 1980; Guseinova, Pavlovskii, Ustinov 1984; Borodkin, Milov 1984; Akimov, Sergeev 1988; Bokarev 1989; Koval'chenko 1991; Borodkin, Svishchev 1992; Nosevich 1994) (the latter are well studied and widespread in Russian cliometricians' works). However, we cannot state that there is no ambiguity as to the specifics, limitations and application possibilities in the history of different models with a dominating deductive origin, as well as to their application while developing one or another mathematical apparatus. Identification of the ratio of simulation and analytical models, that are not related to reflective measurement ones, is of some interest. The problems of the ratio of a model of the analysed historical process, the theories that provide its explanation and the empirical data available as well as the problems of verification of models of different types seem to be essential in this context. We hope that consideration of these issues will improve the adequacy of computer models used in historical research.

Computer analytical models focused on the research of unstable historical processes have been developed in the course of the last decade.

\section{Nonlinear models of historical processes}

A.Yu. Andreev's, L.I. Borodkin's and I.M. Levandovskii's, et al. works (Andreev, Borodkin, Levandovskii 1998) reflect a growing interest of global science in nonlinear dynamics models as an effective approach to the analysis of nonstationary, unstable processes. Such concepts as "catastrophe theory", "synergetics", "bifurcation", "chaos", "strange attractors" are in the lexicon of different sciences, approaching the brink of what has been defined as "cognizing the complexity" by I. Prigogine, a Nobel prize winner. These concepts have found their application in the research of social conflicts dynamics as well as stock-exchange dynamics in the beginning of the XX century (Andreev, Borodkin 2003; Andreev, Borodkin, Konovalova, Levandovskii 2001). Consideration of the logic of these models development and their interpretation requires a more detailed analysis which this section of the paper is focused on. 
The place of social conflicts is special in this range of problems. It should be noted that nature and dynamics of social conflicts are largely determined by the processes of information transfer and diffusion. Carrying over into an unstable society, these processes can lead to an unexpected turn of events. Quite a number of their evidences can be found in the socio-political history of Russia of the late XIX - early XX centuries. All types of information influence and information channels in the society - speeches of the leaders of political movements, legal or illegal propaganda activities of public and political organizations and parties, distribution of leaflets and other printed publications, press materials should be taken into account by the researchers of social conflicts of the new and contemporary time. These processes also include social conflicts in the Russian industry of the late XIX - early XX centuries. Strikes are primarily meant here, though the mass labour movement also took other forms (protests, claims, rallies, demonstrations) in the same information field.

Strike waves belong to those historical processes which, undoubtedly, have internal dynamics and cannot be reduced entirely to the influence of external factors. An interesting result can be obtained by a historian from a non-linear model of strike dynamics, based on endogenous ("internal") factors. It focuses on the research of the processes at micro- or meso-level, taking place in a single information field.

Proposed mathematical model of strike waves (Andreev, Borodkin 2003) involves three differential equations and three variables (the number of striking workers, the number of "agitators", the index of the authorities' activity in suppressing the strikes). The model contains the $a, b, c$ and $m$ coefficients with the following meanings: $b$ - the speed of the strike wave growth in the absence of the authorities' pressure (i.e. the power of cumulative effect of negative factors of the workers' life, encouraging them to protest); $c$ - the power of constraints (potential or real threat from the authorities) in the absence of agitation; $m$ - the efficiency of agitation and $a$ - its increase resulting from the agitators' interaction. All the four parameters characterize the information field of a strike wave development, taking into account various aspects of information dissemination in it. We have found out that the model has an attractor to which the solutions of a system converge regardless of initial conditions on almost the entire interval in which the parameters mentioned were set ${ }^{1}$. This attractor belonged to one of three types: a stable point (the focus), a limiting cycle or a "strange attractor". The results of the analysis of a model behavior under different values of its parameters, leading to qualitatively different regimes (dynamics types), are of great significance. Prior to proceeding to their interpretation it is worth while raising the issue of the advantages of these kinds of models for the researchers of the history of social conflicts in Russia first, the issue also having a more general meaning.

There are many historians who think that the mathematical models can hardly be applied to the research of social processes. Arguing about it is a thankless job, since there have long been scientific schools developing the mathematical simulation methodology and methods in social sciences. Yet, if it is possible to develop mathematical models of current social, economic, political processes, then why not simulate the processes of the past, recent ones or even those that took place long ago? Particularly for the reason that this is an attempt of penetration into the depth of the analysed process. Thus, if every strike and every strike wave in the history of the labor movement in pre-revolutionary Russia bears common traits along with the characteristics of uniqueness and originality, they can not be devoid of interest for a historian, seeking to analyze the mechanisms 
of the development of the social processes of the past. Regarding mass movement, they do not often go beyond the description of events. Description is definitely an essential element of research, but it is not always possible to reach a new analytical level, reveal hidden relations of the elements of the analysed process. We believe that simulation will provide the historians with the approach that brings the researchers of the past together with the analysis of the problems of the present. Concepts and methods of sociology, psychology and other social sciences make it possible to use the tools of detecting causal relations in development of mass movements. Agreeing with the model's proposed structure (i.e. recognizing that formalization of the correlation between the variables in the system of differential equations is adequate, based on natural profound considerations about the structure of strike waves), the historian can gain knowledge about the social process under the reseach while analyzing the model. In this case it is possible, firstly, to identify the typology of dynamic situations in the process development and, secondly, to identify the spheres of parameter values of the analysed systems in which one or another particular type of dynamics is realized. The spheres of particular interest might be those ranges of parameter values in which the process is unstable, i.e. the system responses to external disturbance become dramatically disproportionate. Identification of such regime in the dynamics of the process under the analysis significantly expands the context of understanding the nature of sharp changes in its development, describes the limits of its predictability.

Analysis of the proposed computer model of strike movement has revealed three types of dynamics. Each of them has its own attractor, to which the solutions of a system of differential equations converge independently of initial conditions (i.e. initial values of the number of strikers, levels of agitational activity of left- wing parties and workers' organizations, as well as counter-propaganda of the authorities). It should be emphasized that the type of dynamics is determined by the ratio of the model's control coefficients, which are four in our system of differential equations. These coefficients (model parameters) characterize the properties of the strike movement information field. The analysis of the model has revealed those spheres of values of model parameters in which the model behavior is of a stable or unstable (chaotic) character, depending on the properties of the information environment in which strike waves develop. What types of dynamics ("scenarios" of strike action development) are possible in the behavior of the model developed? Below is a brief content interpretation (summary) of the obtained simulation results, the type of attractor being in its focus.

1) Attractor is a stable point.

Over time, fixed values of all three variables are set in the system, the variables being the number of strikers and agitators, the level of the authorities' pressure ("counter-propaganda"). The word "equilibrium" fits the interpretation of such process. Thus, it describes the balance between the level of agitation and authorities' opposition at a low level of strike activity. Stability of this equilibrium guarantees the absence of "revolutionary explosions" in the system.

\section{2) Attractor is a limiting cycle.}

In the proposed model it is one of the most probable modes, which, in its turn, can be classified (depending on the ratio of individual parameters) into two types.

Type A.

Antagonistic interaction between the strikers and the authorities is coordinated: the increase in the agitators' number corresponds to the authorities' growing opposition, which leads to minimization of influence of agitation and, accordingly, a subsequent reduction of the 
authorities' pressure. Some increase in strike activity is possible only on the phase of the agitators' number growth, but even this process does not go "beyond" the ordinary and, moreover, demonstrates strict periodicity. It is possible to conditionally call this type a strike movement in "civil society": it is adjustable, predictable, and does not go beyond the allocated limits.

Type $B$.

The influence of the "power's authority" drops rapidly, i.e. the government is unable to cope with agitation with their "indirect" methods, and the whole struggle with the strike movement is entirely conferred on the arrests. With the same degree of conditionality, this type describes the strike movement in the "police state" that is stable and predictable under the conditions of an official use of the direct violence methods. It should be also noted that the maximum values of strike activity here are much higher than similar limits in a cycle of type $A$. Thus, type $B$ describes a regular (cyclic) but rather "excited" state of the working environment.

\section{3) A strange attractor.}

In a certain sphere of parameter values the model gives rise to unpredictable behavior, i.e. deterministic chaos ${ }^{2}$. Strange attractors resulting from various combinations of the parameters inside this sphere (just like in case of limiting cycles) can be divided into two types.

\section{Type A'}

The model shows the combination of non-strict periodicity in the agitators' and the authorities' activity with the bursts of strike activity. Basing on our model's structure, it is possible to specify the cause of these bursts: while growing the agitation level will exceed the threshold value for the strike movement growth. Strike activity rapidly grows after that, which, in turn, leads to a sharp decrease in the agitators' number for a negative feedback ("arrests"). Keeping on going down, this number reaches the strike threshold, and, accordingly, the strike movement fades again. It is important that "nonrecurrent" nature of the process pevents accurate prediction of time and value of the next "burst" of strikes. In general, this type of dynamics is characterized by unpredictable "explosions" of strike activity against the background of continuous struggle with the workers and party organizations ("agitators").

\section{Type B'}

A strange attractor here demonstrates the model's nontrivial behavior, representing a kind of a "crossed" version of both types of the limiting cycles $(A$ and $B)$ described above. If the initial level of strike activity is low on the first phase of the process, then the level of its suppression by the authorities grows with an increasing agitation. After that the values of both variables start declining. Further, on the second phase, the agitation growth exceeds the growth of the authorities' opposition and overcomes the threshold of the strikes development, while the authorities' reaction is delayed and remains weak. Strike movement bursts out. After that, on the third phase, the factor of a violent struggle with the agitators comes into action. There is a cyclic change in the agitators' and strikers' number at a still low pressure from the authorities, i.e. the situation of a limiting cycle of type $B$ is repeated. This process is very rapid, sometimes the cycle is even repeated several times before the authorities' suppression starts growing, and then, finally, the system returns to the first phase. Chaotization of the system dynamics here is in the following: each cycle has its own specificity manifested in differences of the strike activity bursts, unpredictability of the peaks frequency. In other words, we deal here with the alternation of relatively long periods of "peaceful" development of strike movement, the authorities' successful struggle with the agitators, and sudden periods of an "explosive" process of strike activity. These 
periods are relatively short, the strike movement within them can not only grow continuously but even have two or more peaks of activity, when the "peaceful" restraint factors lose their role and everything is determined by the violent methods of struggle.

The proposed model to a certain extent proves the thesis on the importance of mastering the analytical tools of the nonlinear, unstable historical processes analysis. In a state of instability of the strike process and at certain parameters of information environment (e.g., near their "threshold" values) the course of events may become unpredictable: minor information signal may cause a burst of strike activity. This model can, in particular, explain when (under what parameters of motion) this happens. Thus, we come to the identification of that phase in the mass processes development which determines the limits of applicability of usual cause-effect relations, loosing their meaning in conditions of instability of the analysed society.

\section{Some words about cliodynamics}

The work of a Russian researchers' group, developing the methods and approaches of cliodynamics, is considered to be the most visible area of computer simulation of historical processes in the first decade of the XXI century. Publications of these group members favour re-evaluation of the possibilities of crisis, transitional and revolutionary processes simulation and development of the WorldSystem in global dimensions and within large time intervals (Korotaev, Malkov, Khalturina 2007; Malkov 2004; Turchin 2007; Problemy matematicheskoi istorii... 2008). This area studies the economic and social dynamics of human development. Among the analysed aspects of society a special attention is given to demography, since the population growth is largely determined by the economic state of the archaic and traditional societies (it still plays an important role in the developing countries). Cliodynamics is characterized by a wide application of the latest macrosociological theories, econometric data and mathematical models of socio-economic processes. On the methodological level cliodynamics analyses the problem of historical time, evolution, progress, and development. At that singleline and multi-line approaches are also used, historical and biological evolution is studied by comparison, with basic empirical regularities and mathematical models. Global demographic and economic processes - monotonic, cyclic, including the hyperbolic growth of the world population and Kremer's, Kapitza's, Tires's mathematical models, as well as the Malthusian theory, neo-Malthusian approaches, demographic and structural-demographic cycles, corresponding mathematical models - are in the focus of cliodynamics. The representatives of this developing area also study technological progress, the processes of dissemination of inventions and innovations, empirical data about these processes and the corresponding mathematical models. Interesting models are based on the data of consumption in economic transformations, in the course of globalization and social change in recent decades (For more details refer to: Alekseev, Borodkin, Grinin, Korotaev, Logunov, Malinetskii, Malkov, Nefedov, Rozov, Turchin, Cherniavskii 2009). The community publishes the Cliodynamics scientific journal, included in Scopus database ${ }^{3}$.

In conclusion, it is worth while noting that computer simulation is more effective in those areas of historical science, in which the conceptual level of knowledge is rather high and there are sources reliable. This explains a relatively successful situation with the computer models application in the socio-economic history research. 
Attractor is a set of points in the phase space of a dynamic system sought by the system trajectories. In this case, attractors correspond to different "scenarios" of strike action characterized by differences in the degree of stability and predictability of the process.

2 Deterministic chaos means the dependence of the system dynamics on the initial conditions: the slightest changes in initial values can lead to large changes in motion trajectory (whereas in "normal state" small changes in initial conditions smooth over in the course of time).

3 http://escholarship.org/uc/irows_cliodynamics

\section{References}

Akimov, V.P., Sergeev, V.M. (1988). Izuchenie struktury konflikta na osnove analiza sobytii: russko-germanskie otnosheniia v 70-kh godakh XIX v. [Conflict Structure Research Based on the Analysis of Events: Russian-German Relations in the 70-ies of the XIX Century]. Matematicheskie metody i EVM vistoriko-tipologicheskikh issledovaniiakh [Mathematical Methods and Computers in Historical and Typological studies]. Moscow.

Alekseev, V.V., Borodkin, L.I., Grinin, L.E., Korotaev, A.V., Logunov, A.P., Malinetskii, G.G., Malkov, S.Yu., Nefedov, S.A., Rozov, N.S., Turchin, P.V., Cherniavskii, D.S. (2009). Istoriia i matematika: protsessy i modeli [History and Mathematics: Processes and Models]. Protsessy i modeli [Processes and Models]. Ed. by Malkov, S.Yu., Grinin, L.E., Korotaev, A.V. Series: History and mathematics. Moscow, 5-14.

Andreev, A.Yu., Borodkin, L.I., Levandovskii, M.I. (1998). Sinergetika v sotsial'nykh naukakh: puti razvitiia, opasnosti i nadezhdy [Synergetics in Social Sciences: Ways of Development, Risks and Hopes]. Krug idei: makro- i mikropodkhody v istoricheskoi informatike [Sphere of Ideas: Macro- and Micro-Approaches in Historical Information Science]. Moscow, 27-52.

Andreev, A.Yu., Borodkin, L.I., Konovalova, A.V., Levandovskii, M.I. (2001). Metody sinergetiki v izuchenii dinamiki kursov aktsii na Peterburgskoi birzhe v 1990-kh gg. [Methods of Synergetics in the Analysis of the Dynamics of Share Prices on St. Petersburg Stock Exchange in 1900s]. Krg idei: Istoriceskaia informatikav iformasionnom obshchese [Sphere of Ideas: Historical Information Science in the Information Society]. Moscow.

Andreev, A.Yu., Borodkin, L.I. (2003). Nelineinaia model' stachechnogo dvizheniia: analiz effektov samoorganizatsii [Nonlinear Model of the Strike Movement: Analysis of the Effects of SelfOrganization]. Krug idei: elektronnye resursy istoricheskoi informatiki [Sphere of Ideas: Electronic Resources of Historical Information Science]. Ed. by L.I. Borodkin, V.N. Vladimirov. Moscow.

Bokarev, Yu.P. (1989). Sotsialisticheskaia promyshlennost' i melkoe khoziaistvo v SSSR v 20-e gody [Socialist Industry and Small Peasant Farming in the USSR in the 20s]. Moscow.

Borodkin, L.I. (1990). Matematicheskie metody v zadachakh modelirovaniia istoricheskikh protsessov i iavlenii [Mathematical Methods for Simulation of Historical Processes and Events]. Perestroika istoricheskogo obrazovaniia v vuzakh strany: opyt, problem, poisk [Restruction of History Education at Russian Higher Education Institutions: Experience, Problems, Search]. Dnepropetrovsk.

Borodkin, L.I. (1995). Kompiuternoe modelirovanie istoricheskikh protsessov: eshche raz o matematicheskikh modeliakh [Computer simulation of historical processes: once again on mathematical models]. Krug idei: razvitie istoricheskoi informatiki [Sphere of Ideas: the Development of the Historical Information Science]. Moscow.

Borodkin, L.I., Milov, L.V. (1984). Nekotorye aspekty primeneniia kolichestvennykh metodov i EVM v istoriko-tipologicheskikh issledovaniiakh [Some Aspects of the Application of Quantitative 
Methods and Computers in the Historico-Typological Research]. Kolichestvennye metody $v$ sovetskoi $i$ amerikanskoi istoriografii [Quantitative Methods in Soviet and American Historiography]. Moscow.

Borodkin, L.I., Svishchev, M.A. (1992). Retroprognozirovanie sotsial'noi dinamiki dokolkhoznogo krest'ianstva: ispol'zovanie imitatsionno-al'ternativnykh modelei [Retro-Forecasting of the Social Dynamics of the Pre-Collective Farm Peasantry: Utilization of Imitative-Alternative Models]. Rossiia i SShA na rubezhe XIX-XX stoletii (Matematicheskie metody vistoricheskikh issledovaniiakh) [Russia and the United States at the End of the XIX-XX Centuries (Mathematical Methods in Historical Research)]. Moscow, 348-365.

Borodkin, L.I., Svishchev, M.A. (1995). Imitatsionnoe modelirovanie protsessa sotsial'nykh peremeshchenii $\mathrm{v}$ chastnom sectore narodnogo khoziaistva perioda heap [Simulation modeling of the process of social movements in the private sector of the national economy of the NEP period]. EVM $i$ matematicheskie metody $v$ istoricheskikh issledovaniiakh [Computer and mathematical methods in historical research], Moscow.

Guseinova, A.S., Kuzishchin, V.I., Pavlovskii, Yu.N., Ustinov, V.A. (1976). Opyt imitatsionnogo modelirovaniia istoriko-sotsial'nogo protsessa [Experience of Simulation of Historical-and-Social Process], In Voprosy istorii [History Issues], 11.

Guseinova, A.S., Pavlovskii, Yu.N., Ustinov, V.A. (1984). Opyt imitatsionnogo modelirovaniia istoricheskogo protsessa [Experience of Imitating Modelling of Historical Process]. Moscow.

Khvostova, K.V. (1980). Kolichestvennyi podkhod v srednevekovoi sotsial'no-ekonomicheskoi istorii [Quantitative approach in medieval social and economic history]. Moscow.

Korotaev, A.V., Malkov, A.S., Khalturina, D.A. (2007). Zakony istorii. Matematicheskoe modelirovanie razvitiia Mir-Sistemy. Demografiia, ekonomika, kul'tura [The Laws of History. Mathematical Modeling of the World-System Development. Demography, Economy, Culture]. Moscow.

Koval'chenko, I.D. (1978). O medelirovanii istoricheskikh iavlenii I protsessov [Modelling of Historical Events and Processes], In Voprosy istorii [History Issues], 8.

Koval'chenko, I.D. (1991). Stolypinskaia agrarnaia reforma (Mify i real'nost') [Stolypin's Agrarian Reform (Myths and Reality)], In Istoriia SSSR [History of the USSR], 2.

Koval'chenko, I.D. (2003). Metody istoricheskogo issledovaniia [Methods of historical research]. Moscow, 407-408.

Malkov, S.Yu. (2004). Matematicheskoe modelirovanie istoricheskoi dinamiki: podkhody i modeli [Mathematical Modeling of the Historical Dynamics: Approaches and Models]. Modelirovanie sotsial'no-politicheskoi i ekonomicheskoi dinamiki [Modeling the Socio-Political and Economic Dynamics]. Ed. M.G. Dmitriev. Moscow.

Matematicheskoe modelirovanie istoricheskikh protsessov: sbornik statei [Mathematical Modeling of the Historical Processes: selected works]. Ed. by L.I. Borodkin. Moscow, 1996.

Nosevich, V.L. (1994). Vetviashchiesia sluchainye protsessy v istorii chelovecheskikh populiatsii [Branching Random Processes in the History of Human Populations]. Kompiuter $i$ istoricheskoe znachenie [Computer and Historical Knowledge]. Barnaul.

Nosevich, V.L. (1996). Na puti k organizatsii obshchestva kak samoorganizuiushcheisia sistemy [Towards Organization of the Society as a Self-Organizing System]. Matematicheskie modeli istoricheskikh protsessov [Mathematical Models of the Historical Processes]. Moscow, 202-223. 
Ponomarev, A.L. (1996). “Chego net, togo ne soschitat'?” Ili skol'ko v Vizantii chekanili monet ["Can One Count What Does Eot exist?" Or How Many Coins Were Minted in the Byzantine Empire]. Matematicheskoe modelirovanie istoricheskikh protsessov [Mathematical Modelling of the Historical Processes]. Moscow, 224-235.

Problemy matematicheskoi istorii: Matematicheskoe modelirovanie istoricheskikh protsessov [The Problems of Mathematical History: Mathematical Modeling of Historical Processes]. (2008). Ed. G.G. Malinetskii, A.V. Korotaev. Moscow.

Turchin, P. (2007). Istoricheskaia dinamika: Na puti $k$ teoreticheskoi istorii [The Historical Dynamics: Towards a Theory of History]. Moscow.

\section{Компьютерное моделирование исторических процессов и явлений: российский опыт}

Л.И. Бородкин

Московский государственный университет им. М.В. Ломоносова Россия, 119991, Москва, Ленинские горы, 1

\footnotetext{
Моделирование исторических проиессов обладает спецификой, характеризующейся тем, что задача моделирования таких процессов не имеет своей целью прогнозирование будущего развития. 3 а 40 лет своего развития это направление исторической информатики в России прошло большой путь. В данной статье предлагается типология подходов к такому моделированию в экономической и сочиальной истории, дается краткий обзор опыта, накопленного российскими историками в этой развивающейся области.

Ключевые слова: компьютерное моделирование, математические модели, имитационное моделирование, контрфактическое моделирование, синергетика, клиодинамика.
}

Научная спечиальность: 07.00.00 - исторические науки. 